\title{
Analisa Perbandingan Model Birokrasi Indonesia: Model Modern David Osborne, Ted Gaebler dan Pendekatan Konsep Islam Perspektif Umer Chapra
}

\section{Comparative Analysis of Indonesia Bureaucratic Model: Modern Model of Osborne and Gaebler and Islamic Concept Approach of Chapra's Perspective}

\author{
Yulizar D Sanrego Nz dan Reza Muhammad \\ Lembaga Penelitian \& Pemberdayaan Masyarakat (LPPM) \\ Sekolah Tinggi Ekonomi Islam Tazkia
}

\begin{abstract}
The inefficiency of public service in Indonesia is one of the results of bad bureaucracy, so that the development system becomes stagnant. On the contrary, sustainable development is a reflection of a good bureaucracy. So far Indonesia is still ranked $100^{\text {th }}$ out of 182 countries in the world for corruption. This paper aims to find out the bureaucratic model in Indonesia within the framework of modern bureaucratic model as well as Islamic Concept approach of Chapra's perspectives. Using content analysis, the paper found that Indonesian bureaucracy model still embrace patrimonial concept that vulnerable to the practice of collusion, corruption and nepotism. While the modern model of Osborne and Gaebler Entrepreneurial Bureaucracy concept with the spirit of innovation and creativity has brought a good change and it is in line with Islamic model of Chapra'sperspective. Chapradescribes that the development of a country should be run simultaneously with the bureaucracy that promotes Islamic values, moral, and hard work. It is concluded that by applying this concept, bureaucracy in Indonesia will be more effective in removing socio-economic problem and will come up with more efficient and sustainable development dimensions.
\end{abstract}

Keywords: Bureaucracy Model, Socio-economic diseases, Efficiency, Development.

\begin{abstract}
Abstrak. Kemunduran pembangunan di Indonesi merupakan salah satu bentuk representasi sistem birokrasi yang buruk. sehingga penyakit sosio - ekonomi menjangkiti pemerintahan Indonesia dan membuat sistem pembangunan menjadi tersendat dan stagnan. Cerminan birokrasi yang baik adalah pembangunan yang berkelanjutan. Tetapi hingga saat ini Indonesia masih berada di peringkat ke- 100 dari 182 negara di dunia untuk masalah korupsi. Paper ini bertujuan ingin mengetahui bagaimana model birokrasi yang ada di Indonesia, birokrasi modern dan pendekatan model Islam perspektif Umer Chapra dalam transformasi birokrasi. Paper ini menggunakan metode pendekatan Content Analysis. Berdasarkan kesimpulan dari studi literatur yang dilakukan, diketahui bahwa model birokrasi Indonesia saat ini masih menganut konsep patrimonial yang rentan aksi kolusi, korupsi, dan nepotisme. Sedangkan model modern David Osborne dan Ted Gaebler dengan konsep Entrepreneurial Bureaucracy dengan semangat inovasi, dan kreativitas telah membawa perubahan yang baik dan itu sejalan dengan model Islam perspektif Umer Chapra yang menjelaskan dalam pembangunan sebuah negara haruslah berjalan simultan dengan tatanan birokrasi yang mengutamakan nilai Islam, moral, dan kerja keras. Dengan penerapan konsep ini maka tatanan sistem birokrasi di Indonesia akan lebih efektif menghilangkan penyakit sosio ekonomi dan dimensi pembangunan akan lebih efisien dan berkelanjutan
\end{abstract}

Kata kunci: Birokrasi, Penyakit Sosio - Ekonomi, Efisiensi, Pembangunan 


\section{Latar Belakang}

Satu demi per-satu masalah terus mendatangi bangsa yang dikenal akan kekayaan rempahnya ini, salah satu dari sekian masalah itu adalah rapuhnya kondisi dan sistem birokrasi yang dimiliki oleh pemerintahan Indonesia. Dimulai dari penyakit korupsi, kolusi, hingga nepotisme $(\mathrm{KKN})$. Hal ini dibuktikan melalui data yang dikeluarkan $\mathrm{TI}^{1}$ (Transparancy International), menempatkan Indonesia pada rangking 100 dari 182 negara dunia dengan nilai 3.0. ${ }^{2}$ Meskipun sedikit lebih baik dari tahun sebelumnya yakni 2011, tetapi negara seribu pulau ini masih sejajar peringkatnya dengan negara Suriname dan Malawi dalam peringkat korupsi. Data tersebut tentunya mengejutkan sekaligus menunjukan bahwa sistem birokrasi yang saat ini diterapkan di negara Indonesia masih dalam tatanan mencari jati diri.

Model birokrasi yang saat ini dijalankan, tidak menunjukan sebuah sistem yang mewakili sifat keadilan, transparasi, dan efisien. Hal ini dalam Islam telah diatur dengan seksama, bahwasanya pandangan hidup Islam didasarkan pada tiga hal fundamental yaitu tauhid (keesaan Allah), khilafah, dan keadilan. ${ }^{3}$ Meskipun penting memaksimalkan sebuah sumber daya agar tercapai output yang maksimum, tetapi dalam Islam tidak hanya mengenal ini saja. Islam mengajarkan dalam rangka mencapai kesejahteraan/kebahagiaan di dunia dan juga di akhirat (falah), harus seimbang antara usaha yang dikeluarkan oleh seorang individu dengan aspek rohaninya serta permainan yang fair pada semua peringkat interaksi manusia. ${ }^{4}$

Merujuk pada berita yang dilansir oleh Metro TV News, sesuai dengan survei yang dilakukan oleh LSI (lembaga survei Indonesia) menempatkan DPR sebagai institusi terkorup di Indonesia tahun 2012. ${ }^{5}$ Maka bukan sebuah rahasia umum lagi ada indikasi pegawai negeri sipil banyak melakukan praktek KKN. Selain itu sistem birokrasi yang berjalan lambat khususnya dalam proses perizinan semakin menguatkan tentang lemahnya sistem birokrat di negeri maritim ini. Dampak yang dirasakan akibat sistem birokrat seperti ini telah dirasakan oleh negeri ini, dalam bidang investasi dengan jenuhnya penanaman investasi asing (PMA), serta beberapa proyek pemerintah yang tidak efektif dan cenderung high cost.

Agenda reformasi orde baru yang telah berlangsung 14 tahun seakan menjadi tidak mempunyai arti perubahan yang besar bagi negeri ini. Di salah satu memorandum yang dituntut oleh para mahasiswa saat itu adalah penghapusan KKN (kolusi, korupsi, nepotisme) dalam sistem pemerintahan. Sudah sangat jelas agenda reformasi ini sangat ditunggu aksinya, sehingga reformasi birokrasi ini tidak cocok hanya ditaruh di tataran isu saja yang cenderung bersifat administratif, dimana hanya membicarakan kenaikan gaji PNS, penataan jabatan, serta rasionalisasi pengurangan dan penambahan pegawai. ${ }^{6} \mathrm{Hal}$ ini tidak akan berhasil bila mempertahankan opsi ini tanpa memperhatikan aspek kultural maupun moral yang ada.

\footnotetext{
${ }^{1}$ TI adalah Transparacy International, sebuah lembaga pemeringkat korupsi tingkat dunia yang telah diakui sertifikasinya dan berkedudukan di Jerman. TI mengeluarkan hasil di setiap akhir tahun untuk 182 negara mengenai tingkat korupsi.

${ }^{2}$ Sumber : Annual Report TI (Transparancy International) 2011, www.TI.org.com Pada tahun 2010 Indonesia memperoleh poin 2.8

${ }^{3}$ M. Umer Chapra. Islam dan Pembangunan Ekonomi. 2000.Gema Insani Press:Jakarta. Hal : 6.

${ }^{4}$ M. Umer Chapra. Islam dan Pembangunan Ekonomi. 2000.Gema Insani Press:Jakarta. Hal : 8.

${ }^{5}$ Berita Metro TV News, Senin 09 Januari 2012. Pkl 03.00 Wib.

${ }^{6}$ Prof. Didin S. Damanhuri. Ekonomi Politik Dan Pembangunan.2010. IPB Press:Bogor. Hal 135.

Jurnal al-Muzara'ah, Vol. I, No. 1, 2013
} 
Gambar 1. Grand Design Reformasi Birokrasi Rep. Indonesia 2014-2025

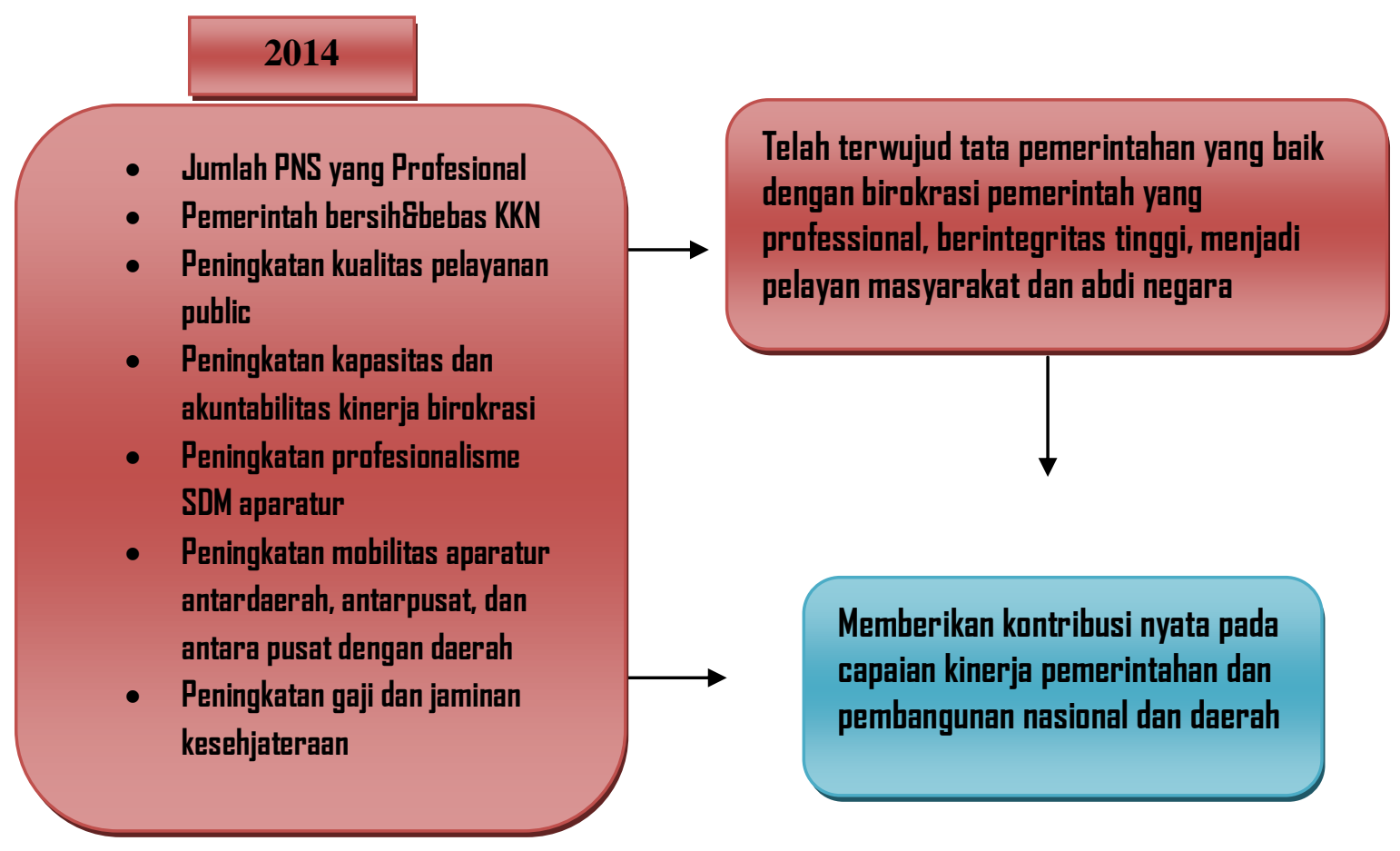

Sumber : Diolah dari Kementrian Pendayagunaan Aparatur Negara Dan Reformasi Birokrasi

Melihat dari Undang-Undang No. 28 Tahun 1999 dalam Pasal 1 poin kedua dijelaskan bahwa, Penyelenggara Negara yang bersih adalah Penyelenggara Negara yang menaati asas-asas umum penyelenggaraan negara dan bebas dari praktek korupsi, kolusi, dan nepotisme, serta perbuatan tercela lainnya. ${ }^{7}$ Berlandaskan dengan hal ini, pemerintah Indonesia sangat aktif untuk bisa mewujudkan tatanan birokrasi yang bersih, salah satu jalan yang ditempuh oleh pemerintah adalah dengan membuat Grand Design Reformasi Birokrasi 2010-2014 dan Road Map Reformasi Birokrasi 2010-2025 yang di sahkan melalui PER/04/M.PAN/4/2009 tentang pedoman pengajuan dokumen usulan reformasi birokrasi di lingkungan kementrian/lembaga/daerah. ${ }^{8}$ Grand Design Reformasi Birokrasi 2010-2014 terangkum dalam tabel dibawah ini:

\footnotetext{
${ }^{7}$ Sumber : www.esdm.go.id

${ }^{8}$ Sumber : Dipublikasikan oleh Kementrian Pendayagunaan Dan Aparatur Negara Dan Reformasi Birokrasi 21 Desember 2010, terkait :"Grand design Reformasi Birokrasi 2010-2025". 
Gambar 2. Grand Design ReformasiBirokrasi Rep. IndonesiaTahun 2010 - 2014

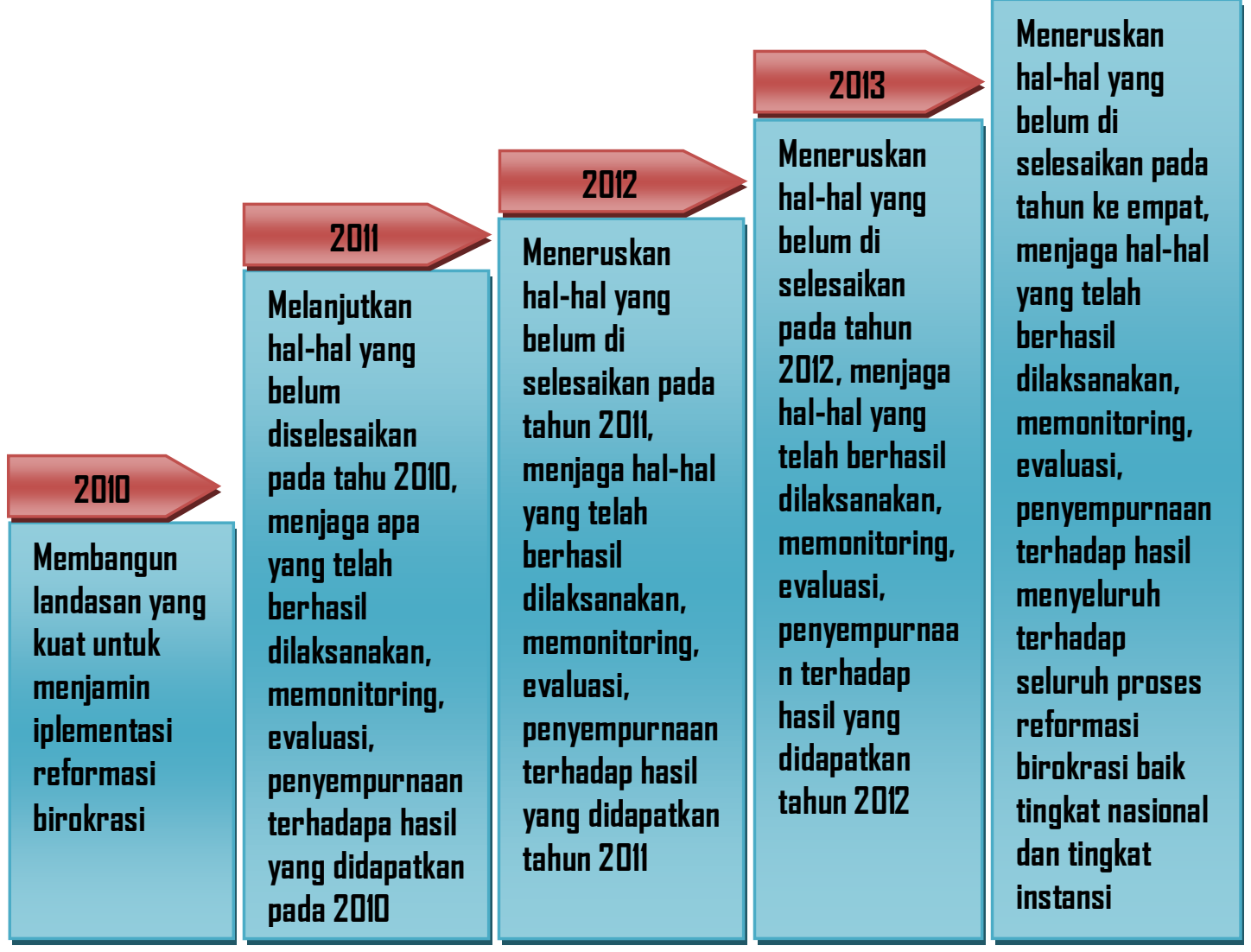

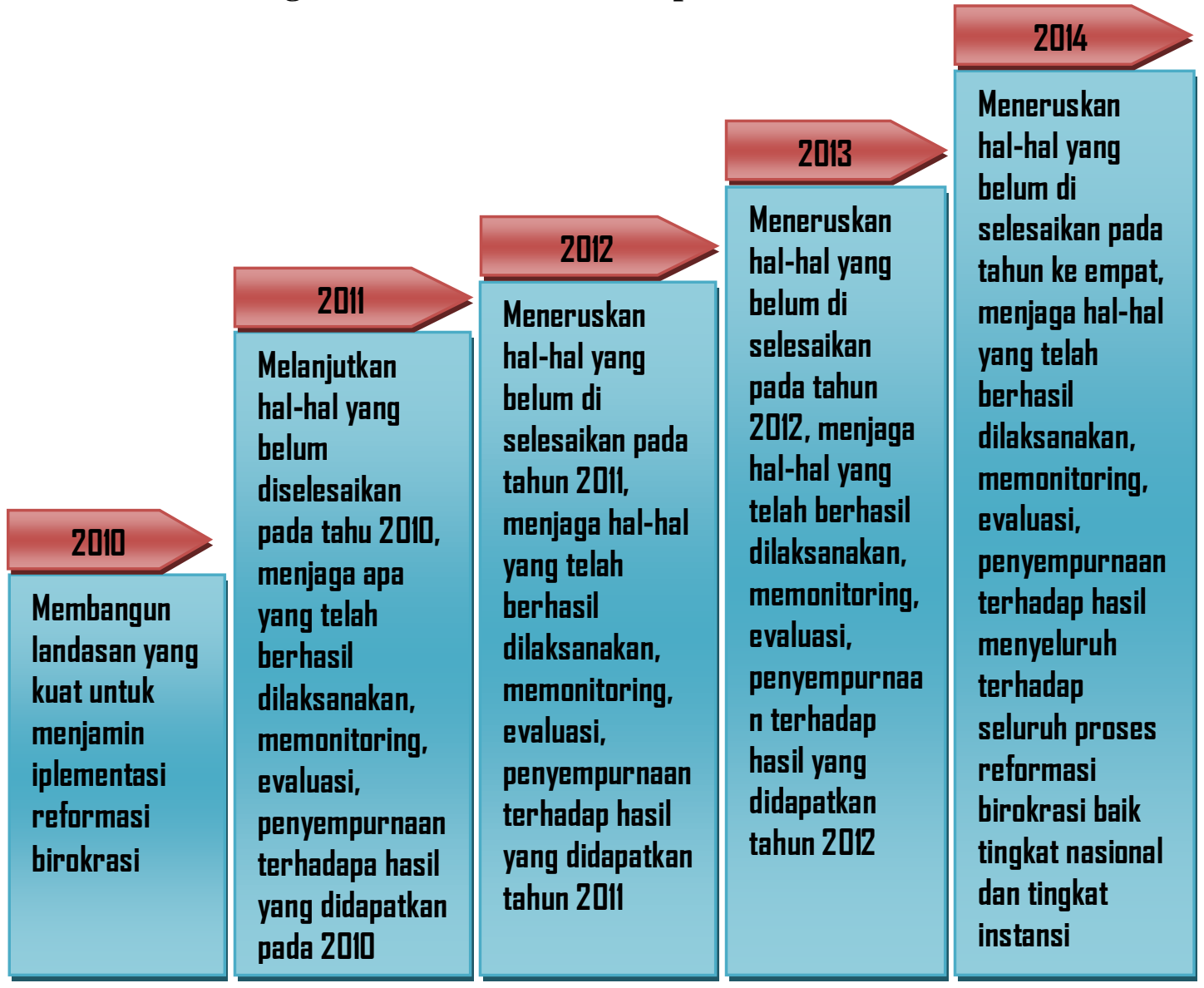

Sumber : Kementrian Pendayagunaan Aparatur Negara Dan Reformasi Birokrasi Republik Indonesia

Gambar diatas menjelaskan beberapa tahapan dalam membangun desain reformasi birokrasi dari tahun 2010-2014, dimulai dari membangun landasan, meneruskan hal-hal yang belum sempat terlaksana dengan evaluasi dan pengawasan terhadap seluruh proses reformasi birokrasi. Hal ini adalah suatu langkah baik yang disusun oleh pemerintah dalam menuju tatanan birokrasi publik yang baik. Diharapkan pada tahun 2025 nanti sistem birokrasi pemerintahan Indonesia telah mencapai Good Governance sehingga dapat memudahkan segala bentuk komunikasi dalam merangsang pembangunan nasional.

Di lain sisi, ada suatu bentuk model birokrasi yang dirancang oleh David Osborne dan Ted Gaebler mengenai sistem birokrasi dalam bukunya. ${ }^{9}$ Buku ini membahas tentang sistem birokrasi yang ada selama ini masih mengajarkan tentang sistem hutang budi (Politisasi Birokrasi) yang berujung pada inefesiensi produktivitas serta kecenderungan operasional praktek KKN. Model Osborne dan Gaebler ini mengajak kalangan pemerintahan untuk menumbuhkan semangat wirausaha dalam sektor publik untuk meningkatkan efektifitas peran birokrasi tersebut.

Penulisan paper ini disusun menggunakan metode pendekatan Content Analysis, yaitu metode penelitian yang digunakan untuk meneliti data-data dengan cara mempelajari, meneliti, dan mengkaji bahan-bahan pustaka/literatur yang relevan. Penulis banyak menggunakan data sekunder yaitu buku-buku rujukan yang relevan dalam mengkaji mengenai sistem birokrasi ini termasuk dalam model birokrasi modern, Indonesia, serta pendekatan model Islam perspektif Umer Chapra.

\footnotetext{
${ }^{9}$ David Osborne Dan Ted Gaebler. Mewirausahakan Birokrasi: Mentrasnformasi Semangat Wirausaha Ke Dalam Sektor Publik.1999.Pustaka Binaan Pressindo:Jakarta. 
Terjadinya ketidakseimbangan dalam sistem birokrasi di Indonesia akan mudah membuat penyakit-penyakit sosio-ekonomi semakin tumbuh subur. Seperti korupsi, inefesiensi anggaran, penurunan produktivitas, dan lambatnya sistem birokrat dalam melaksanakan program tertentu. Berangkat dari hal tersebut, penulis ingin membahas bagaimana transformasi birokrasi dalam mempengaruhi efisiensi pembangunan Indonesia. Kemudian penulis ingin membandingkan dengan model birokrasi yang dijalankan saat ini di Indonesia dengan model birokrasi modern ${ }^{10}$ serta pendekatan model birokrasi Islam perspektif Umer Chapra.

\section{Landasan Teori}

\subsection{Pengertian Birokrasi}

Dalam kamus besar bahasa Indonesia ${ }^{11}$ dijelaskan bahwa birokrasi adalah: pertama, sistem pemerintahan yang dijalankan oleh pegawai pemerintah karena telah berpegang pada hierarki dan jenjang jabatan; kedua, cara bekerja atau susunan pekerjaan yang serba lamban, serta menurut tata aturan (adat sebagainya) yang banyak liku-likunya dan sebagainya.

Pada kamus besar bahasa Indonesia edisi ketiga mendefinisikan birokrasi adalah: pertama, sistem pemerintahan yang dijalankan oleh pegawai bayaran yang tidak dipilih oleh rakyat; $k e d u a$, cara pemerintahan yang sangat dikuasai oleh pegawai. ${ }^{12}$

\subsection{Teori - Teori Birokrasi}

\section{Teori Birokrasi Klasik Karl Marx}

Pada tahun 1845, teori Marx yang disebut sebagai materialisme historis, sudah mencapai tahap perkembangan yang matang dan ide-idenya tentang negara, terutama tentang negara kapitalis telah mencapai final. Marx memandang birokrasi tidak lebih dari sebuah bentuk pengorganisasian yang mau tidak mau harus digunakan oleh kaum Borjuis, untuk menjaga, menjamin hak kepemilikan dan kepentingan mereka. ${ }^{13}$ Marx memandang bahwa negara sebenarnya masih bisa memiliki indepedensi, tetapi itu hanya bisa terjadi asalkan para pemilik kekayaan besar dalam artian proposal dan belum digeser oleh kelas-kelas modern, dimana tidak ada satu kelompok tertentu dalam masyarakat yang bisa menguasai kelompok lain. $^{14}$

Marx disini mencoba menjelaskan bahwa peranan para birokrat juga masih ditentukan oleh beberapa kelompok Borjuis dalam memenuhi keinginan mereka, sehingga independensi yang diharapkan oleh sistem pemerintahan tidak akan mucul. Sistem birokrasi yang masih kacau dan penuh dengan syarat intervensi membuat birokrasi berjalan pada jalanya sendiri tanpa adanya perbaikan yang komprehensif pada seluruh tatananya.

\section{Teori Birokrasi Max Weber}

Max Weber dikenal sebagai Bapak Birokrasi Dunia. Kerangka pemikiran Weber dapat ditemukan dalam ide-idenya mengenai kekuasaan, dominasi, dan kewenangan. Dalam pandangan Weber, kekuasaan adalah probabilitas bahwa seorang pelaku dalam hubungan sosial akan berada pada posisi dimana ia bisa melaksanakan kegiatan sekalipun ada

\footnotetext{
${ }^{10}$ Model Birokrasi David Osborne dan Ted Gaebler.

${ }^{11}$ Kamus Besar Bahasa Indonesia edisi pertama. Jakarta: Balai Pustaka. 1989. Jakarta. Hal 120.

${ }^{12}$ Kamus Beasr Bahasa Indonesia. Edisi Kedua. Jakarta: Balai Pustaka, 2002. Hal 156.

${ }^{13}$ Karl Marx dalam Eva Etzioni, Halevy. Demokrasi dan Birokrasi "sebuah dilema politik". Yogyakarta: Total Media. 2011. Hal 13.

${ }^{14}$ Karl Marx dalam Eva Etzioni, Halevy. Demokrasi dan Birokrasi "sebuah dilema politik". Yogyakarta: Total Media. 2011. Hal 15. 
hambatan. Menurut Weber, kewenangan dikatakan ada ketika kepatuhan itu diberikan atas dasar keyakinan terhadap legimitasi atau keabsahan dari perintah itu. ${ }^{15}$

Ada tiga jenis kewenangan berdasar klaimnya atas legimitasi ${ }^{16}$ : pertama, kewenangan tradisional, yaitu kekuasaan dan dominasi yang dilegitimasi oleh waktu, yaitu karena ia sudah ada sejak lama atau dengan kata lain karena disucikan oleh tradisi. Kedua, kewenangan karismatik dan dominasi yang dilegimitasi oleh karakterisitik kepemimpinan pribadi dari sang pemegang kewenangan. Ketiga, kewenangan legal rasional adalah kekuasaan dan dominasi yang di legimitasikan oleh aturan-aturan formal dan hak dari mereeka yang mendapatkan kewenangan untuk memberikan perintah sesuai dengan aturanaturan itu.

Selanjutnya juga birokrasi harus diberdayakan oleh para pemimpin demokratik untuk mendorong pelembagaan economic society. ${ }^{17}$ Ketiga karakteristik yang tadi disebutkan oleh Weber adalah sebuah acuan dalam segala bentuk organisasi. Untuk birokrasi dijelaskan secara baik di poin ketiga. Karakteristik ini begitu sangat penting dalam sistem pemerintahan, dimana kaitanya dengan aturan yang merupakan harga mati yang harus dipatuhi oleh semua birokrat dalam penyelenggaraan pelayanan publik.

\section{Teori Birokrasi Moderen David Osborne\&Ted Gaebler}

David Osborne dan Ted Gaebler melalui bukunya "Mewirausahakan Birokrasi (mentransformasi semangat wirausaha ke dalam sektor publik)," membuat sebuah skema baru dalam mentransformasi tatanan birokrasi yang ada melalui wirausaha birokrasi. ${ }^{18}$ Menurut David Osborne "persoalan utama yang dihadapi oleh pemerintah dewasa ini bukan terletak pada apa yang dikerjakan, tetapi terletak pada bagaimana mengerjakanya."

Teori yang dikemukakan oleh David Osborne dan Gaebler ini mencoba merubah paradigma sebuah birokrat, bagaimana seorang birokrat diajarkan untuk efektif, efisien dalam menggunakan jabatanya dan memaksimalkan pelayanan ke publik. Dalam ringkasan tabel dibawah ini akan dijelaskan bagaimana langka-langkah penyusunanya dalam transformasi semangat wirausaha dalam tubuh birokrasi. ${ }^{19}$

\footnotetext{
${ }^{15}$ Weber, M. The Teory of Sosial and Economic Organization. New York. New York: The Free Pers. 1947. Hal 152.

${ }^{16}$ Karl Marx dalam Eva Etzioni, Halevy. Demokrasi dan Birokrasi "sebuah dilema politik”. Yogyakarta: Total Media. 2011. Hal 41.

${ }^{17}$ Didin S. Damanhuri. Korupsi, Reformasi Birokrasi Dan Masa Depan Ekonomi Indonesia. Jakarta: LP-FEUI. Hal 15.

${ }^{18}$ Sarundajang. Birokrasi Dalam Otonomi Daerah "upaya dalam mengatasi kegagalan”. Jakarta

Selatan: Kata Press. Hal 261.

${ }^{19}$ David Osborne, Ted Gaebler. Mewirausahakan Birokrasi "mentransformasi semangat wirausaha ke sektor publik". 


\section{Gambar 3. Langkah Penyusunan Transformasi Semangat Wirausaha dalam Tubuh Birokrasi}

\section{Persyaratan}

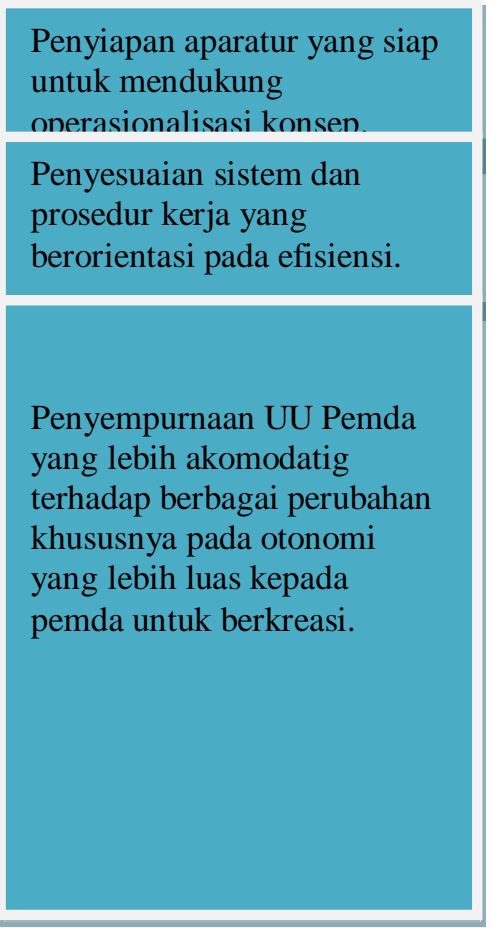

\section{Reivention}

Transformasi dasar sistem pemerintahan dan organisasi pemerintahan untuk meningkatkan efektivitas, efisiensi, kemampuan beradaptasi, dan berinovasi.

\author{
Kemampuan Baru
}

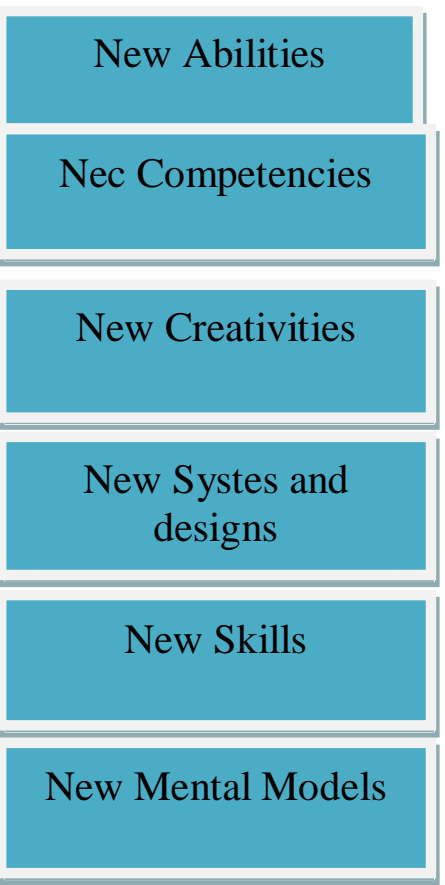

Sumber : Data di olah dari Teori David Osborne\&Ted Gaebler (Mewirausahakan Birokrasi). ${ }^{20}$

Ini adalah langkah yang tepat bagi sebuah tatanan sistem pemerintah dalam meningkatkan efektifitas seorang birokrat khususnya. Tetapi sebenarnya secara partial beberapa konsep reiventing telah dicoba untuk diterapkan. Menurut Sarundajang, persyaratan utama agar konsep reivinting ini dapat diterapkan secara maksimal adalah penyiapan aparatur negara untuk mendukung operasionalisasi konsep tersebut. Penyesuaian sistem dan prosedur kerja yang berorientasi pada efisiensi, penyempurnaan UU daerah yang lebih akomodatif untuk memberikan kewenangan kepada Pemerintah Daerah atau Pemerintah Pusat untuk lebih berkreasi. $^{21}$

${ }^{20}$ David Osborne, Ted Gaebler. Mewirausahakan Birokrasi “mentransformasi semangat wirausaha ke sektor publik".

${ }^{21}$ Sarundajang. Birokrasi Dalam Otonomi Daerah “upaya dalam mengatasi kegagalan”. Jakarta Selatan: Kata Press. Hal 261.

Jurnal al-Muzara'ah, Vol. I, No. 1, 2013 


\section{Teori Pengelolaan Sumber Daya Insani dan Negara Perspektif Umer Chapra}

Merujuk kepada Umer Chapra, seorang ahli ekonomi Islam yang telah teruji melalui berbagai karyanya, bahwa dalam pembangunan suatu negara, aparatur negara menjadi elemen yang sangat signifikan dalam mempengaruhi laju pertumbuhan. Faktor sosio ekonomi menjadi tolak ukur akan keberhasilan pembangunan dalam sebuah negara. Menurut Umer Chapra, ${ }^{22}$ menjadi hal yang sangat dibutuhkan dalam memperkuat nilai-nilai moral dengan melakukan rekstrukturisasi sosio-ekonomi dalam suatu cara yang memungkinkan individu memenuhi kepentingan diri mereka hanya dalam batas-batas kesehjateraan sosial. Dan rekstrukturisasi itu harus bertujuan :

1. Mentransformasi faktor manusia dalam pembangunan untuk menjadikanya mampu berperan aktif dan konstruktif dalam alokasi sumber daya yang efisien dan merata.

2. Mereduksi konsentrasi kepemilikan sarana-sarana produksi yang kini sedang berjalan sebanyak mungkin untuk melengkapi peran transformasi moral dalam meminimalkan pengaruh kekuasaan dan kekayaan dalam alokasi dan distribusi sumber-sumber daya.

3. Mengeliminasi segala bentuk konsumsi "berlebihan" dan "tidak perlu" baik pada tingkat swasta maupun pemerintah dalam rangka meningkatkan tabungan dan memperbesar volume sumber daya yang tersedia untuk investasi dan pemenuhan kebutuhan.

4. Melakukan reformasi sistem keuangan sedemikian rupa sehingga mampu berperan secara komplementer dalam rekstrukturisasi di atas.

Allah berfirman di dalam surat $\mathrm{Al}$ Anbiya ${ }^{23}$ mengenai manusia yang di amanahkan sebagai khalifah di dalam muka bumi ini:

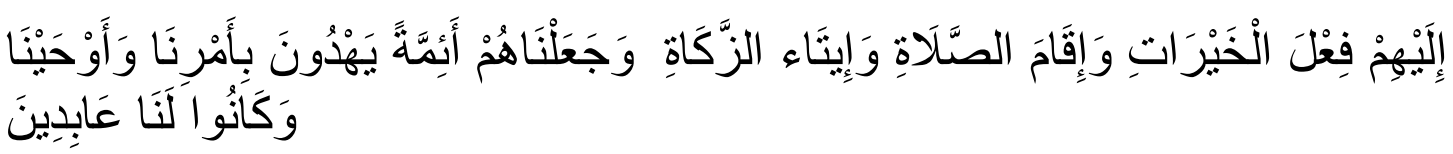

Kami telah menjadikan mereka itu sebagai pemimpin-pemimpin yang memberi petunjuk dengan perintah Kami dan telah Kami wahyukan kepada, mereka mengerjakan kebajikan, mendirikan sembahyang, menunaikan zakat, dan hanya kepada kamilah mereka selalu menyembah.

Di dalam surat As Shoffat ${ }^{24}$ juga dijelaskan secara detail bagaimana perilaku dan tanggung jawab seorang pemimpin dalam menjalankan amanahnya untuk memakmurkan bumi dan masyarakat di dalamnya.

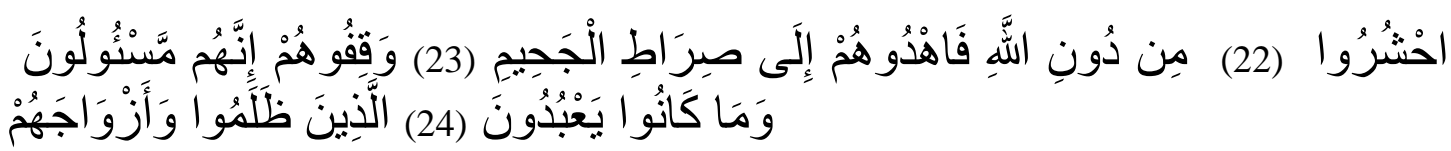

22.(kepada Malaikat diperintahkan): "Kumpulkanlah orang-orang yang zalim beserta teman sejawat mereka dan sembahan-sembahan yang selalu mereka sembah, 23. selain Allah; Maka tunjukkanlah kepada mereka jalan ke neraka. 24. dan tahanlah mereka (di tempat perhentian) karena Sesungguhnya mereka akan ditanya:

Fenomena yang banyak terjadi dalam sebuah negara dalam mendatangkan kemakmuran bangsanya melalui investasi karena adalah urusan birokrasi yang terlalu bertele-tele dan tidak profesional. Hal ini menjadi hal yang diabaikan oleh pemerintah, di sisi lain pemerintah terlalu fokus kepada tujuan-tujuanya yang bersifat materialisme. Sehingga

${ }^{22}$ Empat tujuan rekstrukturisasi sosio-ekonomi dalam Umer Chapra. Islam dan Pembangunan Ekonomi. Jakarta: Gema Insani Press. Hal 83.

${ }^{23} \mathrm{Al}$ Qur'an. Surat Al Anbiya Ayat 73.

${ }^{24} \mathrm{Al}$ Qur'an. Surat As Shoffat Ayat $22-24$. 
kontrol reformasi pada birokrasi yang bersifat non-materi tidak pernah disentuh. Islam mengajarkan kebebasan dalam kerangka nilai dan norma yang harus selalu berjalan secara simultan dengan syariat. ${ }^{25}$

\subsection{Ekonomi Pembangunan}

Menurut Damanhuri, ${ }^{26}$ ekonomi pembangunan adalah sebuah studi disiplin yang mempelajari fenomena yang terjadi di negara sedang berkembang (NSB) dalam kaitanya dengan persoalan kualitas dari Pertumbuhan Domestik Bruto (PDB), mengatasi kemiskinan, pengangguran dan ketimpangan di negara sedang berkembang melalui teori-teori ekonomi pembangunan yang ada. Menurut Mankiw, pembangunan dalam sebuah negara tidak akan terlepas jauh dari GDP (gross domestic bruto) sebagaimana digambarkan dalam persamaanya:

$$
Y=C+I+G+N X^{27}
$$

Notasi G adalah government purchase adalah segala bentuk barang dan jasa yang dibeli oleh pemerintah pusat, negara, bagian, dan daerah. Kelompok ini meliputi para birokrat di instansi militer dan pemerintahan. ${ }^{28}$

Sedangkan menurut Umer Chapra, ${ }^{29}$ ekonomi pembangunan adalah sebuah formulasi tindakan untuk membangun sebuah negara dengan adil tanpa adanya sekularisme antar tatanan sistem pemerintahan dengan moral values dalam agama. Karena kaitanya dengan mensejahterakan masyarakat melalui berbagai regulasi pengurangan kemiskinan, penanaman modal sosial yang baik melalui norma dan budaya yang berlaku serta mengikutsertakan selalu etika dalam setiap aktifitas.

Etika serta perlindungan norma melalui nilai-nilai agama menjadi yang utama di dalam menjalankan sebuah aktifitas. Terkait dengan aktifitas ekonomi, Islam selalu melindungi segala bentuk penyimpangan dengan menjaga tujuan dari setiap diri. Hal ini yang dikenal dengan Maqhasid Syariah yang memenuhi dan menjamin lima hal (dharuriyah al khomsah):

1. Keselamatan keyakinan agama

2. Keselamatan akal

3. Keselamatan jiwa

4. Keselamatan keluarga dan keturunan

5. Keselamatan harta benda

Kelima jaminan ini merupakan tiang penyangga kehidupan umat manusia agar dapat hidup dengan aman dan sejahtera dalam kerangka memperoleh falah tidak hanya di dunia tetapi juga di akhirat sebagai bentuk implementasi seorang manusia sebagai hamba Allah. ${ }^{30}$

\footnotetext{
${ }^{25}$ Umer Chapra. Islam Dan Tantangan Ekonomi. Jakarta. Gema Insani Press. Hal 308.

${ }^{26}$ Didin S. Damanhuri. Ekonomi Politik dan Pembangunan "teori, kritik, dan solusi bagi Indonesia dan negara sedang berkembang”. Bogor : IPB Press. Hal 2-3.

${ }^{27} \mathrm{Y}=$ pendapatan negara, $\mathrm{C}=$ konsumsi, $\mathrm{I}=$ Investasi, $\mathrm{G}=$ Government Expenditure, $\mathrm{NX}=$ Ekspor neto (Ekspor - Impor).

${ }^{28}$ N. Gregory Mankiw. Makroekonomi edisi keenam. Jakarta : Erlangga.

${ }^{29}$ Umer Chapra. Islam dan Tantangan Ekonomi. Jakarta : Gema Insani Press. Hal 84.

${ }^{30}$ Muhammad Abu Zahrah. Ushul Fiqh. Jakarta : Pustaka Firdaus.

Jurnal al-Muzara'ah, Vol. I, No. 1, 2013
} 


\section{Penelitian Terdahulu}

Eko Prasojo dan Teguh Kurniawan, ${ }^{31}$ dalam papernya yang berjudul Reformasi Birokrasi Dan Good Governance: Best Practices Dari Sejumlah Daerah melihat bagaimana pengaruh reformasi birokrasi dalam pembangunan sebuah negara, karena sebuah negara yang bagus adalah dari sisi politik yang kuat dimana birokrasi bermain di dalamnya memainkan fungsinya secara baik dan sesuai perintah. Melihat kesuksesan yang diterapkan di beberapa daerah dengan sistem Good Governance menunjukan daerah tersebut bisa bergerak lebih jauh dalam pembangunanya, sehingga pergerakanya simultan dengan yang diperoleh oleh daerah tersebut.

Ini menunjukkan bahwa reformasi birokrasi sangat nyata dibutuhkan dalam sebuah negara khususnya negara berkembang dan negara maju. Karena laju kendali pemerintahan sangat tergantung bagaimana individu terbaik duduk di dalamnya.

Penelitian yang dilakukan oleh Mahmudi dalam papernya yang berjudul New Public Management: Pendekatan Baru Manajemen Sektor Publik. membahas tentang konsep New Public Management dan dampaknya ke negara-negara berkembang, yaitu Indonesia. ${ }^{32}$ Sebagai gerakan global manajemen, New Public menjadi isu penting dalam manajemen modernisasi organisasi sektor publik di seluruh dunia. Selain New Public Management (NPM), ada beberapa konsep dari manajerialisme di sektor publik, yaitu Reinventing Government, Pasar Berbasis Administrasi Publik, dan Pasca Birokrasi Paradigma. Semua yang mendukung pendekatan konsep manajerial, sebagai menentang untuk pendekatan administrasi, dalam mempromosikan organisasi sektor publik. Artikel ini mengeksplorasi inti dari pendekatan Manajemen Publik Baru, manfaat dan risiko dari NPM, dan masalah yang dihadapi oleh negara-negara berkembang dalam menerapkan NPM.

Konsep NPM ini harus dipelajari lebih dalam lagi, karena konsep ini tergantung bagaimana keadaan lokal setiap negara. Paper ini mencoba melihat bagaimana kemungkinan konsep New Public Management ini diterapkan di Indonesia, tetapi konsep NPM ini meniadakan adanya birokrasi yang masih belum teratur. Sedangkan untuk saat ini Indonesia mempunyai masalah birokrasi yang mempunyai penyaki-penyakit sosio-ekonomi sehingga menghambat pembangunan di Indonesia.

Muhammad Husnul Maab dan Muhammad Fauzan dalam papernya Konsep "Masyarakat Madani" sebagai Solusi Mewujudkan Tata Pemerintahan yang Baik", meneliti dan melihat konsep Masyarakat Madani untuk diterapkan sebagai solusi untuk tata pemerintahan yang baik. ${ }^{33}$ Dalam hal ini Husnul dan Fauzan melihat sistem sosial yang diterapkan di Indonesia dirasa kurang tepat, dan perlu alternatif lain seperti Sistem Sosial Masyarakat Madani (MM) yang dikembangkan dibeberapa negara sedang berkembang dan Negara Eropa Timur.

Untuk mengurangi tindak korupsi dan keteledoran pemerintah dalam memberikan pelayanan, maka menurut konsep MM (masyarakat madani) perlu adanya pembenahan etika, yakni orientasi para birokrasi perlu diluruskan, karena etika merupakan langkah-langkah dan perilaku yang lahir dari seseorang dalam mewujudkan orientasi. Oleh karena itu untuk mendapatkan etika yang baik maka perlu didasari dengan orientasi yang baik, tidak lain adalah orientasi pada masyarakat dan pelayanan publik.

\footnotetext{
${ }^{31}$ Eko Prasojo \& Teguh Kurniawan. Reformasi Birokrasi dan Good Governance: Best Practices Dari Sejumlah Daerah. Working Paper Fak. Ilmu Sosial \& Politik Universitas Indonesia. Tulisan ini dipresentasikan dalam 5th International Simposium Journal of Antropologi at Banjarmasin 2008.

${ }^{32}$ Mahmudi (Fak. Ekonomi UII). New Public Management (NPM): Pendekatan Baru Manajemen Publik. Vol. 6 No. 1, 2003. Hal: 69 - 76. ISSN : 1410 - 9018.

${ }^{33}$ M. Husnul Ma'ab dan Muhammad Fauzan. Konsep Masyarakat Madani sebagai solusi Mewujudkan Tata Pemerintahan yang Baik. Magister Ilmu Administrasi UNSOED. Telah dipresentasikan pada Simposium Nasional Asosiasi Ilmuwan Administrasi Negara (SIMNAS ASIAN) ke - 2 di Univ. Slamet Riyadi Surakarta, pada tanggal 10 Februari 2012. 
Birokrasi yang beretika dan bermoral merupakan modal awal bagi tatanan baru atau reformasi pemerintahan Indonesia. Di samping mengembangkan etika sebagai langkah internal serta penguatan payung hukum dan peningkatan kualitas SDM, dari sisi eksternal juga perlu ada perubahan antara lain pengembangan nilai-nilai pluralisme dan demokrasi, kesamaan hak dan partisipasi serta sinergitas.

Damanhuri dalam papernya mengenai Indonesia, Globalisasi Perekonomian \& Kejahatan Internasional menulis mengenai Globalisasi perekonomian yang telah menjadi hard fact bagi semua negara termasuk berlaku di negara-negara sedang berkembang (NSB). ${ }^{34}$ Bagi sebagian negara, terutama bagi negara industri maju (NIM) telah mendatangkah berkah. Namun bagi sebagian besar lainnya, terutama sebagian besar NSB belum banyak mambawa manfat, bahkan tak sedikit menimbulkan bencana baik berupa makin membengkaknya kemiskinan dan pengangguran serta menajamnya ketimpangan.

Namun bersamaan pula makin marak dan canggihnya kualitas kejahatan (tindak pidana) baik di tingkat nasional maupun internasional, termasuk tidak pidana ekonomi. Dalam tulisan ini diuraikan bagaimana kepentingan Indonesia dengan memahami latar belakang dan ekonomi, social dan historical setting terjadinya globalisasi, dampak positif dan negatifnya globalisasi, kewaspadaan menghadapi globalisasi, dampak globalisasi terhadap perekonomian terutama bagi Indonesia dan dampak globalisasi dalam bentuk kejahatan ekonomi internasional.

Dengan semakin majunya peradaban yang ada di duina saat ini, menimbulkan sebuah dilema baru dalam perilaku pelaku ekonominya. Salah satunya adalah birokrat yang sangat dekat dalam urusan ini bagi sebuah tatanan sistem pemerintahan, tetapi di balik kemajuan itu dibarengi juga dengan meningkatnya kejahatan International yang semakin membayangi pertumbuhan ekonomi. Salah satunya adalah semakin besarnya penyakit sosio-ekonomi seperti korupsi dan inefisiensi yang menjadi kendala dalam mewujudkan Good Governance.

Selanjutnya adalah paper yang ditulis oleh Hezam Mater O. Al Mutairi yang berjudul Ethics of Adminstration and Development In Islam: A Comparative Perspective. ${ }^{35}$ Hezam dalam paper ini mencoba melihat bahwa timbulnya penyakit sosio-ekonomi dalam tubuh birokrasi tidak jauh dari hilangnya etika dalam individu itu sendiri. Lebih jauh dari itu, Islam memberikan perlindungan terhadap penyakit sosio-ekonomi melalui pelapisan nilai-nilai Islam dalam kerangka syariah, dan selalu bertindak akan segala sesuatu itu di tujuka untuk mencapai keberkahan di dunia dan di akhirat.

Tatanan sistem administrasi yang baik, dan dilakukan secara hati-hati dengan mempertimbangkan nilai, moral, dan etika akan selalu membawa dampak yang baik sehingga penyakit sosio-ekonomi dapat dihindarkan. Pembangunan dalam suatu negara pun dapat ditingkatkan, tidak hanya semata-mata secara kuantitatif tetapi pembangunan dari segi akhlaq, moral, dan etika semakin tinggi. Sehingga individu yang berada di dalam negara tersebut, khususnya di tatanan sistem pemerintahan dapat menjalankan fungsinya dengan baik.

${ }^{34}$ Prof. Dr. Didin S. Damanhuri. Indonesia, Globalisasi Perekonomian \& Kejahatan International. Workings Paper No. 13/A/III/2008. Guru Besar Departemen Ilmu ekonomi, Fakultas Ekonomi dan Manajemen Institut Pertanian Bogor.

${ }^{35}$ Hezam Mater O. Al Mutairi. Ethics Of Administration and Development In Islam : A Comparative Perspective. Journal King Saudi Univ. Vol. 14, Admin. Set (1), pp. 49 -64, Riyadh $(1422 / 2002)$ 
Tabel 1. Rangkuman Penelitian Terdahulu

\begin{tabular}{|c|c|c|c|}
\hline Nama & Topik & Metode & Hasil \\
\hline $\begin{array}{l}\text { Eko Prasojo \& } \\
\text { Teguh } \\
\text { Kurniawan } \\
\text { (2008) }\end{array}$ & $\begin{array}{l}\text { Reformasi Birokrasi dan } \\
\text { Good Governance Di } \\
\text { Indonesia : Kasus Best } \\
\text { Practices sejumlah } \\
\text { Daerah di Indonesia }\end{array}$ & Library Aproach & $\begin{array}{l}\text { Kondisi Politik yang sehat serta tipe } \\
\text { pemimpin menjadi faktor utama di } \\
\text { dalam melakukan reformasi birokrasi } \\
\text { untuk menuju good governance. }\end{array}$ \\
\hline Mahmudi (2003) & $\begin{array}{l}\text { New Public Management } \\
\text { (NPM) Pendekatan Baru } \\
\text { Manajemen Sektor Publik }\end{array}$ & $\begin{array}{l}\text { Kualitatif } \\
\text { Deskriptif }\end{array}$ & $\begin{array}{l}\text { Sebagai sebuah sistem baru, NPM } \\
\text { menawarkan sistem birokrasi yang } \\
\text { sehat kepada negara sedang } \\
\text { berkembang, tetapi perlu dilakukan } \\
\text { pendekatan kultural lokal lebih dalam } \\
\text { kepada tiap negara. Karena iklim di } \\
\text { setiap negara berbeda dan belum tentu } \\
\text { bisa menerima konsep NPM ini. }\end{array}$ \\
\hline $\begin{array}{l}\text { M. Husnul } \\
\text { Ma'ab dan M. } \\
\text { Fauzan (2012) }\end{array}$ & $\begin{array}{l}\text { Konsep Masyarakat } \\
\text { Madani sebagai solusi } \\
\text { Mewujudkan Tata } \\
\text { Pemerintahan yang Baik. }\end{array}$ & $\begin{array}{l}\text { Analysis Content, } \\
\text { Library Approach }\end{array}$ & $\begin{array}{l}\text { Konsep Masyarakat Madani adalah } \\
\text { konsep yang baik untuk tatanan sistem } \\
\text { pemerintahan. Dimana untuk } \\
\text { menciptakan iklim tersebut harus ada } \\
\text { sinergitas antara : community, } \\
\text { government, business, dan Voluntary } \\
\text { dan berporos pada satu hal dalam } \\
\text { rangka mewujudkan Good Governance. }\end{array}$ \\
\hline $\begin{array}{l}\text { Didin S. } \\
\text { Damanhuri } \\
\text { (2008) }\end{array}$ & $\begin{array}{l}\text { Indonesia, Globalisasi } \\
\text { Perekonomian \& } \\
\text { Kejahatan International. }\end{array}$ & $\begin{array}{l}\text { Kualitatif } \\
\text { Deskriptif }\end{array}$ & $\begin{array}{l}\text { Globalisasi yang terjadi saat ini telah } \\
\text { membawa perubahan dalam bebrapa } \\
\text { sektor, termasuk dalam sistem } \\
\text { pemerintahan yang berkaitan dengan } \\
\text { pertumbuhan suatu negara. Tetapi } \\
\text { Indonesia harus dapat mengetahui } \\
\text { dengan baik latar belakang, ekonomi, } \\
\text { sosial dan historical settin. Karena } \\
\text { globalisasi ini bisa membawa dampak } \\
\text { negatif dan positif bagi suatu } \\
\text { pemerintahan Indonesia jika tidak di } \\
\text { cermati. }\end{array}$ \\
\hline $\begin{array}{l}\text { Hezam Mater O. } \\
\text { Al- Mutairi }\end{array}$ & $\begin{array}{l}\text { Ethics Of administration } \\
\text { and Development in Islam } \\
\text { : A Comparative } \\
\text { Perspective }\end{array}$ & Analysis Content & $\begin{array}{l}\text { Kerangka nilai, norma, serta etika } \\
\text { adalah pelindung dalam membuat } \\
\text { tatanan sistem pemerintahan yang baik. } \\
\text { Karena dalam Islam mengenal kata } \\
\text { amanah yang di pangku setiap } \\
\text { pemimpin. Dimana setiap } \\
\text { kepemimpinan tujuan utamanya adalah } \\
\text { menciptakan maslahah dan falah tidak } \\
\text { hanya di dunia tetapi juga di akhirat, } \\
\text { sebagai bentuk implementasi manusia } \\
\text { sebagai hamba Allah. }\end{array}$ \\
\hline
\end{tabular}




\section{Pembahasan}

\subsection{Model Birokrasi Indonesia}

Sebagai sebuah negara yang heterogen dalam berbagai lini, Indonesia yang merupakan salah satu dari lima negara terbesar di Dunia sudah menjadi kewajiban memiliki tatanan sistem pemerintahan yang baik. Karena sampai pada saat ini, Indonesia masih belum bisa terlepas dari masalah sosio-ekonomi. Kolusi, Korupsi, dan Nepotisme dimana hal ini merupakan salah satu rangkaian agenda reformasi tahun 1998 belum dilaksanakan dengan baik.

Birokrasi yang menjadi lini terdepan dalam roda pemerintahan tidak menjalankan fungsinya secara baik, produktivitas yang menurun serta inefisiensi dalam menjalankan fungsi jabatan adalah salah satu faktor penghambat pembangunan di Indonesia. Padahal sumber daya manusia adalah pilar penting pembangunan suatu negara. Setidaknya ada lima hal yang harus dilaksanakan dalam mengembalikan kembali fungsi negara sehingga demokrasi dapat dikonsolidasikan, yakni : Pertama, Birokrasi pemerintahan yang dapat diberdayakan, Kedua, Pengembangan masyarakat sipil yang bebas dan hidup. Ketiga, Masyarakat politik yang secara relatif otonom, Keempat, Supremasi dan tertib hukum, dan Kelima adalah adanya pelembagaan masyarakat ekonomi. ${ }^{36}$

Hal ini selaras dengan teori Max Weber yang menjelaskan bahwa kewenangan dikatakan ada ketika kepatuhan itu diberikan atas dasar keyakinan terhadap legimitasi atau keabsahan dari perintah. ${ }^{37}$ Menurut Weber juga, ada tiga jenis kewenangan berdasar klaimnya atas legimitasi: pertama, kewenangan tradisional, yaitu kekuasaan dan dominasi yang dilegitimasi oleh waktu, yaitu karena ia sudah ada sejak lama atau dengan kata lain karena disucikan oleh tradisi. Kedua, kewenangan karismatik dan dominasi yang dilegimitasi oleh karakterisitik kepemimpinan pribadi dari sang pemegang kewenangan. Ketiga, kewenangan legal rasional adalah kekuasaan dan dominasi yang dilegimitasikan oleh aturan-aturan formal dan hak dari mereka yang mendapatkan kewenangan untuk memberikan perintah sesuai dengan aturan-aturan itu. ${ }^{38}$

Konsep ini selaras dengan penelitian yang dilakukan oleh Eko Prasojo dan Teguh Kurniawan, karena sebuah negara yang bagus adalah dari sisi politik yang kuat dimana birokrasi bermain di dalamnya memainkan fungsinya secara baik dan sesuai perintah. ${ }^{39}$ Diikuti juga dengan karakteristik pemimpin yang baik dan karismatik. Melihat kesuksesan yang diterapkan di beberapa daerah dengan sistem Good Governance menunjukan daerah tersebut bisa bergerak lebih jauh dalam pembangunanya, sehingga pergerakanya simultan dengan yang diperoleh oleh daerah tersebut.

Ini menunjukan, bahwa reformasi birokrasi sangat nyata dibutuhkan dalam sebuah negara khususnya negara berkembang dan negara maju. Karena laju kendali pemerintahan sangat tergantung bagaimana individu terbaik duduk di dalamnya.

\footnotetext{
${ }^{36}$ Didin S. Damanhuri. Ekonomi Politik dan Pembangunan "teori, kritik, dan solusi bagi Indonesia dan Negara Sedang Berkembang. 2010. Bogor : IPB Press. Hal 139.

${ }^{37}$ Weber, M. The Teory Of Sosial And Economic Organization. New York. New York: The Free Pers. 1947. Hal 152.

${ }^{38}$ Karl Marx dalam Eva Etzioni, Halevy. Demokrasi dan Birokrasi "sebuah dilema politik". Yogyakarta: Total Media. 2011. Hal 41.

${ }^{39}$ Eko Prasojo \& Teguh Kurniawan. Reformasi Birokrasi dan Good Governance: Best

Practices Dari Sejumlah Daerah. Working Paper Fak. Ilmu Sosial \& Politik Universitas Indonesia. Tulisan ini dipresentasikan Dalam 5th International Simposium Journal Of Antropologi at Banjarmasin 2008. 
Dalam Grand Design Reformasi Birokrasi yang dirancang oleh Kementrian Pendayagunaan Aparatur Negara dan Reformasi Birokrasi Indonesia tahun 2014 - 2025 juga mengacu pada konsep - konsep di atas. Seperti model dibawah ini :

\section{Gambar 4. Alur Sistem Desain Reformasi Birokrasi Republik Indonesia Tahun 2014 - 2025}

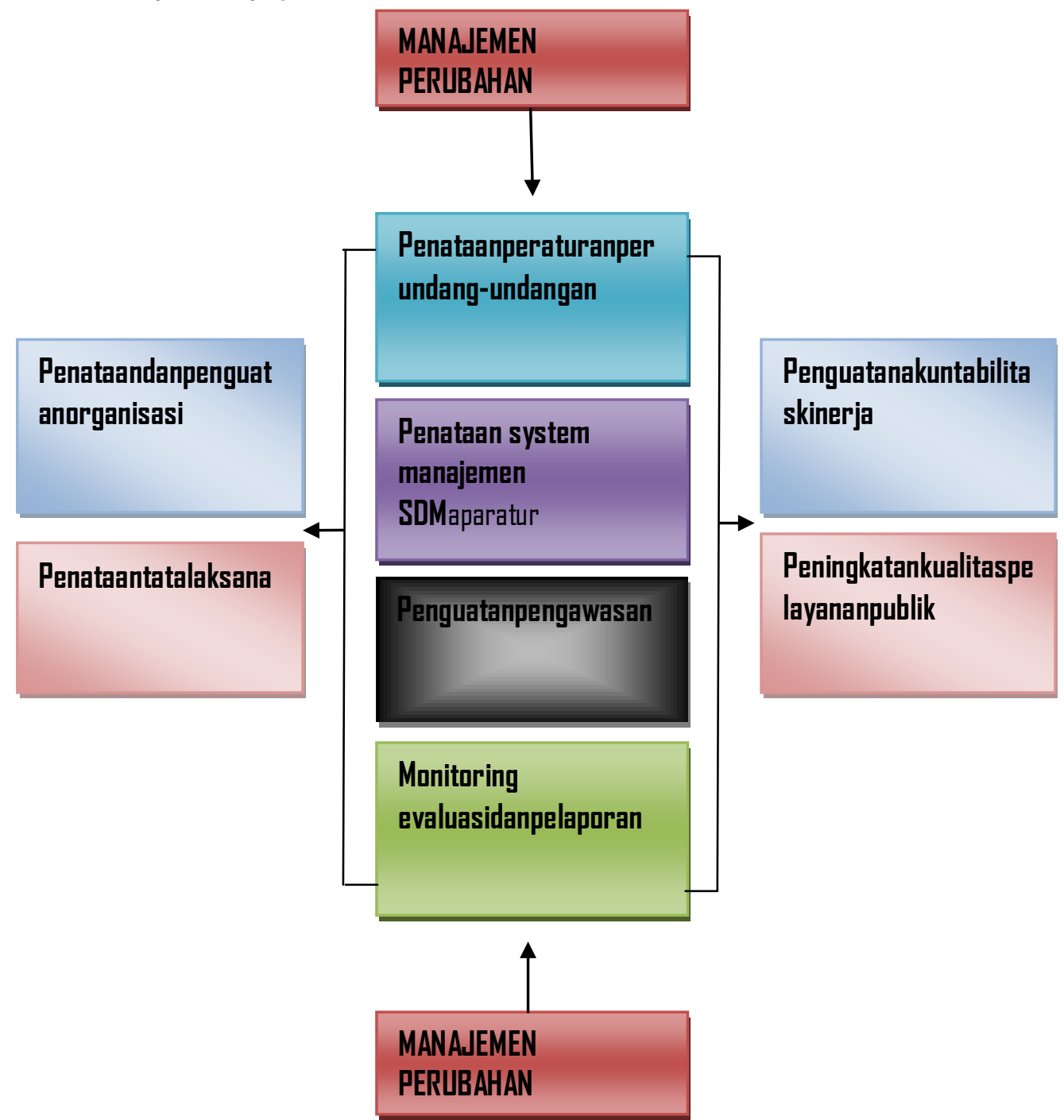

Sumber : Grand Design Reformasi Birokrasi 2014 - 2025, Kementrian Pendayagunaan Aparatur Negara Dan Reformasi Birokrasi Indonesia. ${ }^{40}$

Masing - masing elemen dalam model di atas mewakili apa yang terdapat dalam teori Max Weber, dimana memang harus ada legimitasi, supremasi hukum dalam kerangka Good Governance dan kebijakan pembangunan Indonesia.

Menurut Damanhuri, Indonesia masih memakai sistem Birokrasi patrimonial. Dimana setiap kebijakan dan regulasi yang dikeluarkan dalam kerangka politisasi. Sehingga terciptalah Birokrasi Berpolitik seperti yang ada dalam model di atas. Ini adalah sebuah sistem yang harus dihilangkan dan diperbaiki, karena dengan tetap bertahan pada sistem ini kerangka birokrasi Indonesia akan terus mewarisi penyakit sosio - ekonomi kepada generasi

${ }^{40}$ Sumber : Grand Design Reformasi Birokrasi 2014 - 2025. Kementrian Pendayagunaan Aparatur Negara Dan Reformasi Birokrasi Indonesia 
dibawahnya yang tidak lain adalah kerabat yang memiliki hubungan dekat dengan generasi birokrasi sebelumnya. ${ }^{41}$

\subsection{Model Birokrasi Modern David Osborne dan Ted Gaebler}

Bertahanya penyakit sosio - ekonomi di Negara Sedang Berkembang, termasuk salah satunya di Indonesia tidak jauh dari sistem birokrasi yang masih kita gunakan. Sistem Birokrasi Patrimonial yang dianut oleh Indonesia dan seakan menjadi akar budaya adalah sistem yang semu dan merapuhkan setiap lini di dalam pemerintahan Indonesia dalam pemabangunanya. Kemajuan yang selama ini di dengungkan dalam kerangka demokrasi melalui kebijakan otonomi daerah (OTODA) tidak menunjukkan kemajuan yang signifikan, karena sistem birokrat yang ada belum bisa memahami arti birokrasi sendiri dan cenderung melepaskan kerangka etika dari jabatan yang di amanahkan.

Hal ini selaras dengan penyataan David Osborne dan Ted Gaebler, pengemuka teori Birokrasi Wirausaha bahwa persoalan utama yang dihadapi pemerintah dewasa ini bukan terletak pada apa yang dikerjakan, tetapi terletak bagaimana mengerjakanya". ${ }^{42}$ Hal ini semakin membenarkan, bahwa cara yang digunakan dalam megerjakan sistem birokrasi telah mengalami penyimpangan yang cukup jauh dan tertinggal dari cita - cita birokrasi itu sendiri.

Osborne dan Gaebler menentang teori Weber mengenai Birokrasi yang tidak bisa melakukan transformasi yang ideal. ${ }^{43}$ Osborne dan Gaebler berhasil menemukan sebuah formula dalam mengembalikan bentuk birokrasi sesuai dengan cita - cita birokrasi. Ini selaras dengan penelitian M. Husnul Ma'ab dan M. Fauzan mengenai konsep masyarakat madani yang dijadikan sebagai leading sector dalam sistem birokrasi. Menurut Husnul dan Fauzan melihat sistem sosial yang diterapkan di Indonesia dirasa kurang tepat, dan perlu alternatif lain seperti Sistem Sosial Masyarakat Madani (MM) yang dikembangkan dibeberapa Negara Sedang berkembang dan Negara Eropa Timur. ${ }^{44}$

Untuk mengurangi tindak korupsi dan keteledoran pemerintah dalam memberikan pelayanan, maka menurut konsep MM (masyarakat madani) perlu adanya pembenahan etika, yakni orientasi para birokrasi perlu diluruskan, karena etika merupakan langkah-langkah dan perilaku yang lahir dari seseorang dalam mewujudkan orientasi. Oleh karena itu untuk mendapatkan etika yang baik maka perlu didasari dengan orientasi yang baik, tidak lain adalah orientasi pada masyarakat dan pelayanan publik.

Birokrasi yang beretika dan bermoral merupakan modal awal bagi tatanan baru atau reformasi pemerintahan Indonesia. Disamping mengembangkan etika sebagai langkah internal, serta penguatan payung hukum dan peningkatan kualitas SDM, dari sisi eksternal juga perlu ada perubahan, antara lain pengembangan nilai-nilai pluralisme dan demokrasi, kesamaan hak dan partisipasi serta sinergitas. Dimana untuk menciptakan iklim tersebut harus ada sinergitas antara Community, Government, Business, dan Voluntary dan berporos pada satu hal dalam rangka mewujudkan Good Governance.

\footnotetext{
${ }^{41}$ Prof. Dr. Didin S. Damanhuri. Ekonomi Politik dan Pembangunan "teori, kritik, dan solusi bagi Indonesia dan Negara Sedang Berkembang. 2010. Bogor : IPB Press.

${ }^{42}$ David Osborne Dan Ted Gaebler. Mewirausahakan Birokrasi: Mentrasnformasi Semangat Wirausaha Ke Dalam Sektor Publik.1999.Pustaka Binaan Pressindo:Jakarta.

${ }^{43}$ Sarundajang. Birokrasi Dalam Otonomi Daerah "upaya dalam mengatasi kegagalan”. Jakarta Selatan: Kata Press. Hal 256.

${ }^{44}$ M. Husnul Ma'ab dan Muhammad Fauzan. Konsep Masyarakat Madani sebagai solusi Mewujudkan Tata Pemerintahan yang Baik. Magister Ilmu Administrasi UNSOED. Telah dipresentasikan pada Simposium Nasional Asosiasi Ilmuwan Administrasi Negara (SIMNAS ASIAN) ke - 2 di Univ. Slamet Riyadi Surakarta, pada tanggal 10 Februari 2012. 
Poin Business di atas adalah bentuk dari reivinting bureaucracy dalam mentransformasikan semangat wirausaha. Sehingga sistem birokrasi ini dapat memahami apa yang menjadi tugasnya dan bisa memanfaatkan lebih dari input yang diberikan oleh pemerintah pusat atau daerah, sehingga cita - cita birokrasi dalam mewujudkan tatanan sistem pemerintahan yang baik akan selaras dengan pembangunan negara dalam mencapai tingkat kesehjateraan.

Namun demikian Mahmudi dalam papernya menyatakan tidak sepakat dengan model birokrasi modern dengan sistem yang diutarakan oleh Osborne dan Gaebler. ${ }^{45}$ Dalam papernya tersebut Mahmudi menjelaskan bahwa NPM (New Public Management) adalah sebuah konsep sistem pemerintahan yang dapat memperbaiki kinerja birokrasi. Tetapi konsep NPM ini memerlukan kajian lebih lanjut, karena konsep NPM ini terlebih dahulu melihat segi kultural yang berbeda khususnya di Indonesia yang heterogen ini.

Konsep entrepreunial bureaucracy adalah dengan menciptakan organisasi pemerintahan yang senantiasa inovatif, yang terus memperbaiki kualitasnya tanpa harus tergeser dari luar. ${ }^{46}$ Osborne menjelaskan konsep Wirausaha Birokrasi ini adalah yang paling baik untuk saat ini untuk berbagai negara, baik yang sedang berkembang atau maju. Karena tanpa harus merubah kultural adalah konsep yang cocok bagi Indonesia yang heterogen khususnya. Osborne dan Gaebler memberikan sepuluh prinsip dalam mengadaptasi konsep ini: ${ }^{47}$

1. Pemerintah daerah yang katalis: Mengarahkan bukan melaksanakan.

2. Pemerintah daerah sungguh - sungguh milik rakyat: Memberi wewenag dibanding melayani.

3. Pemerintah daerah yang kompetitif: Menyutikan persaingan dalam pemberian pelayanan.

4. Pemerintah daerah yang melaksanakan visi dan misi.

5. Pemerintah daerah yang berorientasi pada hasil.

6. Pemerintah daerah yang digerakkan oleh pelanggan.

7. Mewirausahakan pemerintah daerah.

8. Pemerintah daerah yang antisipatif.

9. Pemerintah daerah yang disentralisasi: Dari hierarki menuju partisipatif dan tim kerja.

10. Pemerintah daerah yang berorientasi pasar: Mendongkrak perubahan melalui pasar.

Beberapa tawaran mengenai nilai - nilai baru bagi pemerintah daerah tersebut tentunya tidak dapat seluruhnya secara utuh diterapkan dalam organisasi pemerintah daerah, karena berbagai kondisi pemerintah daerah akan sangat mempengaruhi penerapan Reivinting Government tersebut. Namun aspek - aspek substansial dari konsep tersebut pada hakikatnya dapat menjadi kerangka acuan dalam membentuk organisasi pemerintah daerah yang kondusif dalam menghadapi tuntutan persaingan abad ke -21 .

\footnotetext{
${ }^{45}$ Mahmudi (Fak. Ekonomi UII). New Public Management (NPM): Pendekatan Baru Manajemen Publik. Vol. 6 No. 1, 2003. Hal: 69 - 76. ISSN : 1410 - 9018.

${ }^{46}$ Sarundajang. Birokrasi Dalam Otonomi Daerah "upaya dalam mengatasi kegagalan”. Jakarta Selatan: Kata Press. Hal 261.

${ }^{47}$ Sarundajang. Birokrasi Dalam Otonomi Daerah "upaya dalam mengatasi kegagalan”. Jakarta Selatan: Kata Press. Hal 256.
} 


\subsection{Pendekatan Model Birokrasi Islam Perspektif Umer Chapra}

Islam hadir sebagai jalan kehidupan yang adil dan benar, sesuai dengan surat An Nahl ayat 89 :

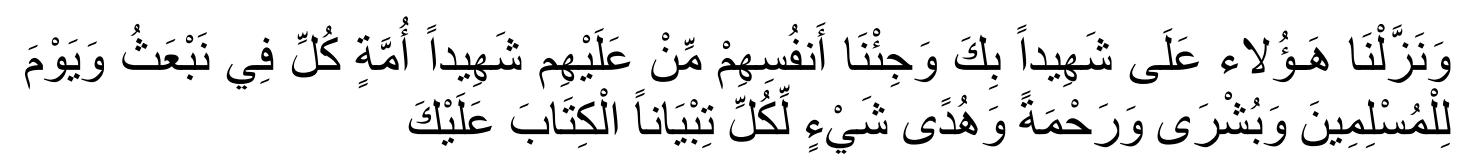

....... (dan ingatlah) akan hari (ketika) Kami bangkitkan pada tiap-tiap umat seorang saksi atas mereka dari mereka sendiri dan Kami datangkan kamu (Muhammad) menjadi saksi atas seluruh umat manusia. dan Kami turunkan kepadamu Al kitab (Al Quran) untuk menjelaskan segala sesuatu dan petunjuk serta rahmat dan kabar gembira bagi orang-orang yang berserah diri.

Segala sesuatu yang berkaitan dengan hidup seorang manusia telah dicukupkan oleh Allah SWT melalui berbagai ni'matnya. Maka kehidupan yang teratur dan sejahtera adalah hanya bagi orang - orang yang mau berfikir dan merenung terhadap kebesaran Allah. Di Surat Al Maidah Allah juga berfirman :

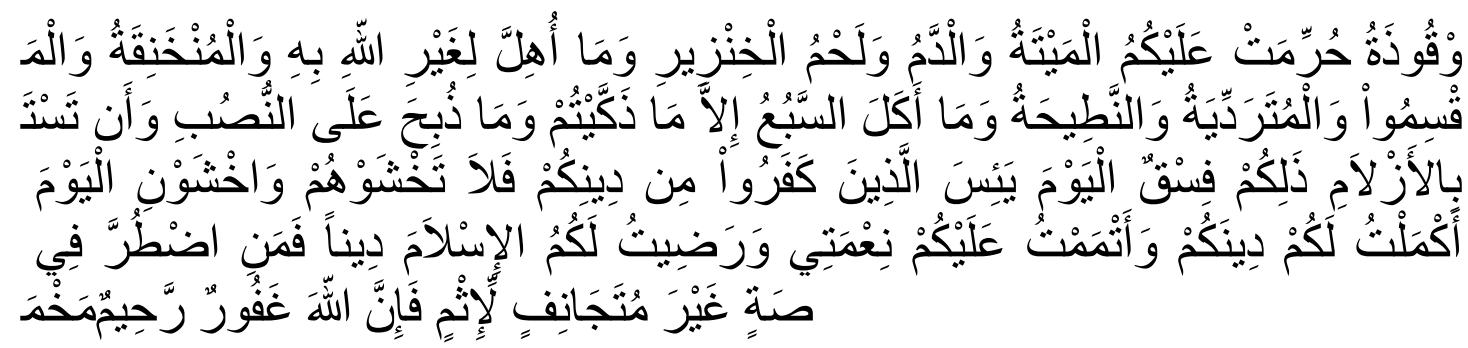

dan takutlah kepada-Ku. pada hari ini telah Kusempurnakan untuk kamu agamamu, dan telah Ku-cukupkan kepadamu nikmat-Ku, dan telah Ku-ridhai Islam itu Jadi agama bagimu.

Umar Chapra menjelaskan bahwa apa yang saat ini dialami oleh sebagian besar Negara Sedang Berkembang adalah sistem pemerintahan yang inkonsisten terhadap pembangunan negara tersebut, sehingga pembangunan daerah tersebut tersendat bahkan tertinggal jauh. Fenomena yang banyak terjadi dalam sebuah negara dalam mendatangkan kemakmuran bangsanya melalui investasi karena adalah urusan birokrasi yang terlalu bertele-tele dan tidak profesional.

Hal ini menjadi hal yang diabaikan oleh pemerintah, di sisi lain pemerintah terlalu fokus kepada tujuan-tujuanya yang bersifat materialisme. Sehingga kontrol, reformasi pada birokrasi tidak pernah disentuh. Islam mengajarkan kebebasan dalam kerangka nilai dan norma yang harus selalu berjalan secara simultan dengan syariat. ${ }^{48}$

Hal senada juga dijelaskan oleh Hezam Mater O. Al Mutairi yang berjudul Ethics of Adminstration and Development In Islam: A Comparative Perspective. Hezam dalam paper ini mencoba melihat bahwa timbulnya penyakit sosio-ekonomi dalam tubuh birokrasi tidak jauh dari hilangnya etika dalam individu itu sendiri. Lebih jauh dari itu, Islam memberikan perlindungan terhadap penyakit sosio-ekonomi melalui pelapisan nilai-nilai Islam dalam kerangka syariah, dan selalu bertindak akan segala sesuatu itu hanaya ditujukan untuk mencapai keberkahan di dunia dan di akhirat. ${ }^{49}$

Menariknya Osborne dan Gaebler dalam konsep Entrepreunerial Bureaucracy secara implisit bersinggungan dengan apa yang dijelaskan oleh Umer Chapra dalam karakter

\footnotetext{
${ }^{48}$ Umer Chapra. Islam Dan Tantangan Ekonomi. Jakarta. Gema Insani Press. Hal 308.

${ }^{49}$ Hezam Mater O. Al Mutairi. Ethics Of Administration and Development In Islam : A Comparative Perspective. Journal King Saudi Univ. Vol. 14, Admin. Set (1), pp. 49 -64, Riyadh (1422/2002) 
sumber daya insani. Di dalam bukunya menjelaskan mengenai sepuluh konsep transformasi dalam birokrasi: ${ }^{50}$

1. Pemerintah daerah yang katalis : Mengarahkan bukan melaksanakan.

2. Pemerintah daerah sungguh - sungguh milik rakyat : Memberi wewenag dibanding melayani.

3. Pemerintah daerah yang kompetitif : Menyutikan persaingan dalam pemberian pelayanan.

4. Pemerintah daerah yang melaksanakan visi dan misi.

5. Pemerintah daerah yang berorientasi pada hasil.

6. Pemerintah daerah yang digerakkan oleh pelanggan.

7. Mewirausahakan pemerintah daerah.

8. Pemerintah daerah yang antisipatif.

9. Pemerintah daerah yang disentralisasi : Dari hierarki menuju partisipatif dan tim kerja.

10. Pemerintah daerah yang berorientasi pasar : Mendongkrak perubahan melalui pasar.

Islam mewajibkan kepada setiaap manusia bekerja keras dan tidak bermalas - malasan sehingga bisa memunculkan kreativitas dan produktivitas yang tinggi. Hal ini seperti yang ada dalam ayal Al Qur'an pada Surat At Taubah ayat ke - 20 yang diperintahkan oleh Allah agar manusia senantiasa berinovasi:

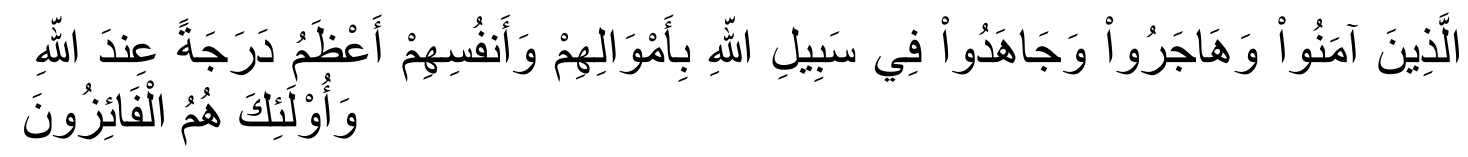

Orang-orang yang beriman dan berhijrah (berinovasi) serta berjihad di jalan Allah dengan harta, benda dan diri mereka, adalah lebih Tinggi derajatnya di sisi Allah; dan Itulah orang-orang yang mendapat kemenangan.

Pemerintah memang telah meletakan pos pengeluaran untuk belanja negara dengan baik, tetapi dalam hal ini pemerintah masih harus melakukan banyak pembenahan. Terutama di sektor infranstruktur dasar yang sangat dibutuhkan sebagai proses pembangunan yang seimbang dan cepat. Pendidikan yang merupakan tiang utama dari sebuah masyarakat juga belum memadai secara baik. Umer Chapra memberikan beberapa alasan mengapa hal seperti inefisiensi ini terjadi: ${ }^{51}$

1. Kurangnya kesadaran bahwa sumber daya yang ada ini adalah milik Allah SWT.

2. Ketiadaan suatu falsafah pembangunan yang lahir dari diri bangsa untuk diselaraskan dengan sumber daya negara dan nilai - nilai telah menyebabkan ketiadaan skala prioritas yang mapan.

3. Ketiadaan suatu parlemen yang terpilih dan kebebasan pers menjadikan rakyat tidak mempunyai suatu forum untuk menyalurkan kritik pada kebijakan pemerintah.

Lanjutnya Umer Chapra menambahkan, hampir bisa dipastikan problem ini sulit diatasi bila tidak ada jaminan partisipasi rakyat banyak dalam pemerintah. Umer Chapra menjelaskan ada beberapa langkah yang bisa dilakukan untuk menuju tatanan sistem pemerintahan yang baik: ${ }^{52}$

1. Mentransformasi faktor manusia dalam pembangunan untuk menjadikanya mampu berperan aktif dan konstruktif dalam alokasi sumber daya yang efisien dan merata.

\footnotetext{
${ }^{50}$ David Osborne Dan Ted Gaebler. Mewirausahakan Birokrasi: Mentrasnformasi Semangat Wirausaha Ke Dalam Sektor Publik.1999.Pustaka Binaan Pressindo:Jakarta.

${ }^{51}$ Umer Chapra. Islam Dan Pembangunan Ekonomi. Jakarta. Gema Insani Press. Hal 116.

${ }^{52}$ Umer Chapra. Islam Dan Pembangunan Ekonomi. Jakarta. Gema Insani Press. Hal 116.

Jurnal al-Muzara'ah, Vol. I, No. 1, 2013
} 
2. Mereduksi konsentrasi kepemilikan sarana-sarana produksi yang kini sedang berjalan sebanyak mungkin untuk melengkapi peran transformasi moral dalam meminimalkan pengaruh kekuasaan dan kekayaan dalam alokasi dan distribusi sumber-sumber daya.

3. Mengeliminasi segala bentuk konsumsi "berlebihan" dan "tidak perlu" baik pada tingkat swasta maupun pemerintah dalam rangka meningkatkan tabungan dan memperbesar volume sumber daya yang tersedia untuk investasi dan pemenuhan kebutuhan.

4. Melakukan reformasi sistem keuangan sedemikian rupa sehingga mampu berperan secara komplementer dalam rekstrukturisasi di atas.

Dimana maksud pemerintahan disini adalah segala sistemnya termasuk bagaimana individu yang ada di level birokrat dalam mengakomodir kebutuhan masyarakat. Pembahasan di atas terangkum dalam kerangka pembahasan pada diagram berikut.

\section{Gambar 5. Model Birokrasi}

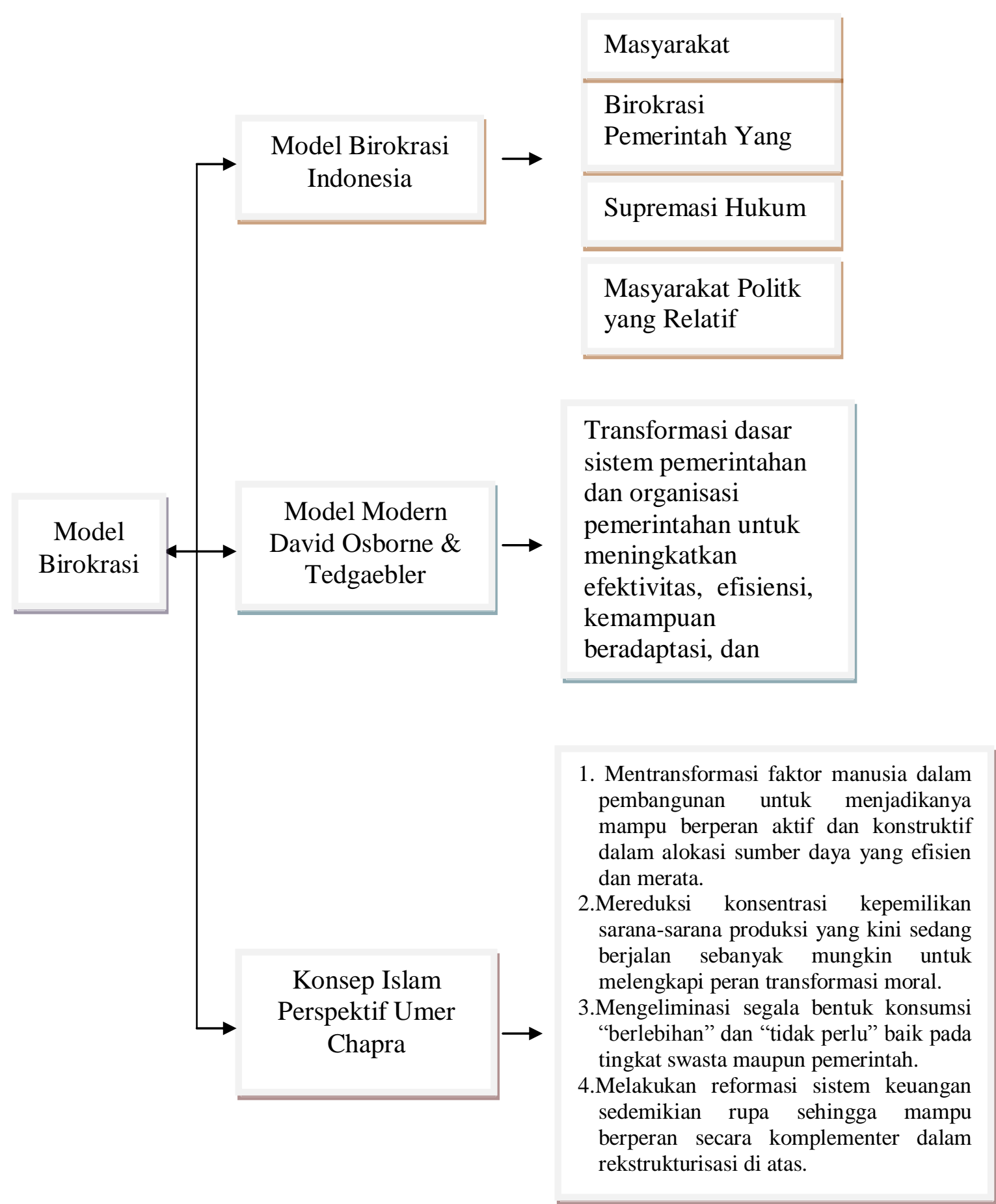




\section{Kesimpulan dan Rekomendasi}

Berbagai studi telah membuktikan bahwa sistem birokrasi adalah salah satu elemen penting dalam sebuah pembangunan dalam negara baik yang sedang berkembang maupun yang telah maju. Teori birokrasi Max Weber yang mengemukakan bahwa aspek sosial dalam birokrat itu harus diikuti dengan legitimasi hukum yang jelas sehingga menimbulkan kepatuhan yang baik. Tetapi melalui teori birokrasi wirausaha David Osborne dan Ted Gaebler mematahkan teori weber.

Osborne dan Gaebler meyatakan bahwa dalam pemerintahan, birokrat memiliki untuk menginovasi dirinya sendiri melalui berbagai kreativitasnya. Makna wirausaha adalah kemandirian tanpa menunggu perintah atau regulasi. Birokrasi digambarkan sebagai sebuah sistem yang terus maju dan berinovasi melalui sepuluh konsepnya:

1. Pemerintah daerah yang katalis : Mengarahkan bukan melaksanakan.

2. Pemerintah daerah sungguh - sungguh milik rakyat : Memberi wewenang dibanding melayani.

3. Pemerintah daerah yang kompetitif : Menyuntikan persaingan dalam pemberian pelayanan.

4. Pemerintah daerah yang melaksanakan visi dan misi.

5. Pemerintah daerah yang berorientasi pada hasil.

6. Pemerintah daerah yang digerakkan oleh pelanggan.

7. Mewirausahakan pemerintah daerah.

8. Pemerintah daerah yang antisipatif.

9. Pemerintah daerah yang disentralisasi : Dari hierarki menuju partisipatif dan tim kerja.

10. Pemerintah daerah yang berorientasi pasar : Mendongkrak perubahan melalui pasar.

Selaras dengan hal itu Umer Chapra menjelaskan bahwa sebuah pembangunan negara tergantung bagaimana kualitas sumber daya insani yang ada di dalam pemerintahan tersebut. Umer Chapra menjelaskan jika di dalam sebuah sistem pemerintahan menyertakan nilai, moral, serta etika maka pembangunan sebuah negara tersebut akan mengalami peningkatan secara otomatis. Restrukturisasi dalam sistem birokrasi ini sangat utama dalam pembangunan sebuah negara, dan rekstrukturisasi itu harus bertujuan :

1. Mentransformasi faktor manusia dalam pembangunan untuk menjadikanya mampu berperan aktif dan konstruktif dalam alokasi sumber daya yang efisien dan merata.

2. Mereduksi konsentrasi kepemilikan sarana-sarana produksi yang kini sedang berjalan sebanyak mungkin untuk melengkapi peran transformasi moral dalam meminimalkan pengaruh kekuasaan dan kekayaan dalam alokasi dan distribusi sumber-sumber daya.

3. Mengeliminasi segala bentuk konsumsi "berlebihan" dan "tidak perlu" baik pada tingkat swasta maupun pemerintah dalam rangka meningkatkan tabungan dan memperbesar volume sumber daya yang tersedia untuk investasi dan pemenuhan kebutuhan.

4. Melakukan reformasi sistem keuangan sedemikian rupa sehingga mampu berperan secara komplementer dalam rekstrukturisasi di atas.

Ketika hal ini diterapkan secara baik dan optimal, maka sistem birokrasi akan menjadi lebih efektif dan pembangunan dalam negara Indonesia akan semakin efisien dan bisa meninggalkan penyakit - penyakit sosio - ekonomi yang saat ini masih berada di dalam tatanan sistem pemerintahan Indonesia.

Paper ini tentunya merupakan studi pendahuluan bagaimana sesungguhnya peran moral menjadi bagian penting dalam memastikan terciptanya pembangunan yang efisien dan berkelanjutan. Perlu penelitian lanjutan secara empiris sebagai rekomendasi penelitian lanjutan yang memberikan kepastian bahwa ada hubungan positif antara kehadiran moral aparatur birokrasi dengan pencapaian tertentu di tingkat nasional. 


\section{Daftar Pustaka}

Al Qur'anKarim. 2008. Departemen Agama Republik Indonesia

Chapra, U. 2000. Islam dan Pembangunan Ekonomi. Gema Insani Press: Jakarta. 2000. Islam dan Tantangan Ekonomi. Gema Insani Press: Jakarta.

Damanhuri, D. S. 2010. Ekonomi Politik da Pembangunan "Teori, Kritik, dan Solusi Bagi Indonesia dan Negara Sedang Berkembang. IPB Press: Bogor.

2006. Korupsi, Reformasi Birokrasi dan Masa Depan Ekonomi Indonesia. LP - FEUI: Jakarta.

2009. INDONESIA : Negara, Civil Society dan Pasar dalam Kemelut Globalisasi. LP - FEUI: Jakarta.

2008. Indonesia, Globalisasi Perekonomian \& Kejahatan International. Workings Paper No. 13/A/III/2008. Guru Besar Departemen Ilmu ekonomi, Fakultas Ekonomi dan Manajemen Institut Pertanian Bogor.

Prasojo, E. dan T. Kurniawan. Reformasi Birokrasi dan Good Governance: Best Practices Dari Sejumlah Daerah. Working Paper Fak. Ilmu Sosial \& Politik Universitas Indonesia. Tulisan ini dipresentasikan Dalam 5th International Simposium Journal Of Antropologi at Banjarmasin 2008.

Etzioni, E. dan Halevy. 2011. Demokrasi dan Birokrasi "Sebuah dilema Politik". Total Media: Jakarta.

Hezam, M. O. A. Ethics Of Administration and Development In Islam : A Comparative Perspective. Journal King Saudi Univ. Vol. 14, Admin. Set (1), pp. 49 -64, Riyadh $(1422 / 2002)$.

Ma'ab, M. H. dan M. Fauzan. Konsep Masyarakat Madani sebagai solusi Mewujudkan Tata Pemerintahan yang Baik. Magister Ilmu Administrasi UNSOED. Telah dipresentasikan pada Simposium Nasional Asosiasi Ilmuwan Administrasi Negara (SIMNAS ASIAN) ke - 2 di Univ. Slamet Riyadi Surakarta, pada tanggal 10 Februari 2012.

Mahmudi (Fak. Ekonomi UII). 2003. New Public Management (NPM): Pendekatan Baru Manajemen Publik. Vol. 6 No. 1, 2003. Hal: 69 - 76. ISSN : 1410 - 9018.

Sarundajang, H. 2012. Birokrasi dalam Otonomi Daerah “Upaya Mengatasi Kegagalan”. Kata Penerbit: Jakarta.

Zahrah, A. 2008. Ushul Fiqh. Pustaka Firdaus: Jakarta. 